Forthcoming in Geoforum

\title{
HYBRIDITY EMERGENT: GEO-HISTORY, LEARNING, AND LAND RESTITUTION IN SOUTH AFRICA
}

\section{Acknowledgements:}

I would like to acknowledge The Mershon Center and Kirwan Center at The Ohio State University for generous funding support. I thank Kevin R. Cox, who provided timely, insightful comments and advice; Nkuzi Development Association in South Africa for invaluable support and encouragement; all the restitution claimants and commercial farmers in Limpopo who gave their time; and the three anonymous referees who encouraged the paper to be pushed in new directions. Any errors are my responsibility. 


\title{
HYBRIDITY EMERGENT: GEO-HISTORY, LEARNING, AND LAND RESTITUTION IN SOUTH AFRICA
}

\begin{abstract}
:
Market-Led Agrarian Reform (MLAR), which is advocated by the World Bank and is being implemented in various contexts around the world, is a more neo-liberal approach to land reform than what we have seen implemented in the past. MLAR principles have underpinned South Africa's land reform programme, being based on the 'willing-seller, willing-buyer' principle, which guarantees market-related prices to sellers. Evidence presented in this paper, however, raises serious questions about the extent to which the South African government has held on to MLAR principles. Specifically, the paper argues that South Africa’s peculiar geo-historical context has in some instances led the government to fuse market-led approaches with more authoritarian interventions that dictate to land reform beneficiaries how the land will be used. A case in point is the government's approach to restitution of land rights to communities dispossessed from the Levubu area of Limpopo province. As the paper illustrates, the government has imposed on the intended beneficiaries a so-called 'strategic partnership' between them and agribusinesses. Although the government touts the approach as a way to protect the commercial viability of the land and to transfer skills from white farmers to the beneficiaries, the terms of the Levubu solution may turn out to be less than favourable for the beneficiaries.
\end{abstract}

Keywords: South Africa, Restitution, Land reform, Limpopo 


\section{HYBRIDITY EMERGENT: GEO-HISTORY, LEARNING, AND LAND RESTITUTION IN SOUTH AFRICA}

\section{Introduction}

South Africa's Restitution of Land Rights Act 22 of 1994 'gives effect to the constitutional provision that people unfairly dispossessed after 1913 are entitled either to restitution of that property or to compensation’ (Hall, 2004 p.12). Almost 80,000 claims for restitution were lodged with the Commission on the Restitution of Land Rights, which was established by the Act to 'solicit and investigate claims for restitution and to prepare them for settlement' (ibid.). If progress in restitution is measured in terms of the number of claims settled, the pace of delivery has increased dramatically in recent years. According to Hall, 'By the end of August 2004, a cumulative total of 56650 claims had been settled, resulting in the transfer of $810292 \mathrm{ha}$ of land (just under $1 \%$ of all agricultural land in the country) at a cost of abut R1.5 billion’1 (op cit p.13). Yet, given that 'R2.5 billion had been paid out or promised to claimants as cash or other forms of compensation', and that only 36\% of claims have been settled with land (Hall, 2004 p.13), restitution has made only very limited strides in undoing the racialized character of land ownership in South Africa. However, there are now signs that land transfers under restitution are increasingly on the government's agenda; the 2005 National Budget, for example, allocated greatly increased amounts to restitution over the coming three-year period: R2.71bn in 2005/06, or an increase of 134\%, R3.69bn in 2006/07 and R3.83bn in 2007/08 (Umhlaba Wethu, 2005). Although it remains unclear whether a higher proportion of claims will be settled with land, signs are that the government is intending that that should be the case.

$\overline{\text { US\$1 = approximately R6.2. }}$ 
One area of the country in which numerous claims for restitution have been lodged and yet remain largely unsettled is in the far north of Limpopo province. The claims have been lodged by people (or their descendants) dispossessed from 1913 onwards of their land in the vicinity of the Soutpansberg Mountains. Some of the claims refer to land on which white farmers, with farreaching assistance from successive whites-only governments, have created profitable, intensive, export-oriented farm businesses. A case in point is the group of claims for restitution of land in Levubu, an export-oriented agricultural area of around 10 000ha, which employs thousands of workers and for which purchases of supplies and equipment contribute to the economies of nearby towns such as Makhado and Thohoyandou (see Figure 1). The government has recognised the validity of seven claims for restitution in Levubu, Yet it has been hesitant about settling them and directly transferring the land to the claimants without attaching far-reaching conditions. A major source of the government's hesitance is the fear that claimants lack the skills and know-how to manage the land and maintain commercial, agricultural enterprises. ${ }^{2}$ Experience elsewhere in South Africa, including in Limpopo, has shown that direct transfers without sufficient 'post-settlement support' (Jacobs, 2003; Hall, 2004) can lead to restitution failures that are a source of embarrassment to the government as well as a threat to its visions for development. The government's ‘solution’ to this problem in Levubu has been to privatise postsettlement by brokering deals between agribusinesses and claimants that will lead to fifteen-year 'strategic partnerships'. Each of the claimant communities will form a Joint Venture Company

\footnotetext{
2 Bradstock (2004) noted, for example, that 'while land reform groups have individuals who have worked on white commercial farms the majority of members have no theoretical or practical knowledge of farming' (p.1); that apartheid denied beneficiaries opportunities to attain skills requisite to intensive commercial agriculture almost goes without saying.
} 
[JVC] with one of two Limpopo-based agribusinesses (hereafter referred to as strategic partners [SP]); the JVC will pay an annual lease to its respective community; any profits from the managed land will be divided between the SP and the community; and the SP will launch a skills transfer plan to ensure that members of the community will have the know-how to take control of the land at the end of the fifteen-year period. It is under these conditions that the first 4 000ha or so of Levubu farms acquired by the government from 'willing sellers' will be managed. ${ }^{3}$ The government has insisted that the land will not be transferred to the claimants if they do not agree to enter into partnerships. What is remarkable about the Levubu case, then, is just how far the government has gone to impose on the claimants its ideas about how the land should be used. As with similar restrictions that have been imposed in other parts of the country on how claimants can use transferred land, ${ }^{4}$ the government is telling the rightful landowners - rightful, that is in terms of the liberation ideology of the ANC - what they can and cannot do.

\section{[INSERT FIGURE 1 ABOUT HERE]}

Given this as my point of departure, the aims of this paper are twofold. In the first place I want to explain how all this has come about. I position the Levubu case in the wider literature on land reform because the process leading up to the Levubu settlement and the underlying tensions it

3 It remains unclear whether the government will acquire the remaining 6,000ha via expropriation. There are no indications at the time of writing (January 2006) that the state will exercise its expropriation powers.

$4 \quad$ Claims on national parks, such as the Makuleke claim in Kruger National Park (Ramutsindela, 2002), have been settled without full transfer of ownership rights. Thus, titles have been transferred under strict conditions: some claimants find that 'they may not sell, mortgage, lease or lend - nor do they have unfettered scope to use the land themselves' (Hall, 2004 p.22). 
illustrates are emblematic of land questions that continue to rankle in other settler societies in Africa (Bernstein, 2002, 2004; Moyo \& Yeros, 2005; Peters, 2004), much of Latin America, including Brazil (Sauer, 2001; Wolford, 2003), Central America (Kay, 2001; Bobrow-Strain, 2004), as well as in Asia (Aguilar, 2005; Borras, 2005). Evidence from studies in these places is mounting of a change in how states try to address land questions, how, in other words, they undertake land reform. According to some, the phase of 'state-led' or 'developmentalist' redistributive land reform has been displaced by a 'new wave'(Bernstein, 2002), market-friendly thrust to land reform exemplified by policies that commit states to pay market-related prices for redistributed land, or demand-driven redistribution programmes (Deininger, 1999). The rise of this new wave is strongly associated with the ascendancy of neo-liberal approaches in social and economic policy more generally. Yet, to some extent, and it bears emphasis, the distinction between state-led and market-friendly approaches is a false one. This is because market-friendly policies always require extensive state involvement (Jessop, 2002; Harvey, 2005). A more accurate characterisation might be that 'new wave' policies give more, rather than less, scope to market processes (see Borras, 2003, 2005).

It is generally accepted that South Africa has rolled out the World Bank's neo-liberal ideas about using the market more than the state to deal with landlessness (e.g. see Deininger, 1999). Attention has been drawn to the South African government's commitment to protecting private property rights and its promise to paying market-related prices for transferred land, hence avoiding 'fast track' expropriation such as has occurred in Zimbabwe (Lahiff and Cousins, 2001; Bernstein, 2004). Of course, completing the restitution programme requires extensive state involvement - which, as already noted, in general terms can be said of most programmes 
affected by neo-liberal principles - and which has led some to argue that the overall land reform programme in South Africa is a hybrid case (Levin and Weiner, 1997). However, the way the government has acted as the guardian of the interests of the claimants of the Levubu farms and imposed far-reaching restrictions on how they can use the land suggests that it has learned to move beyond rigid adherence to market-led principles. Thus, although the land has been acquired from willing sellers, which reflects the market-led influence, restrictions on how the claimants can use the land are nothing if not stentorian. After starting with goals clearly informed by neo-liberal principles, then, the South African state seems to have moved in its restitution programme towards favouring projects which are not only hybrid in form, but in which the state role verges on the authoritarian. It is for this reason that I refer to the restitution 'solution' in Levubu as a fusion of market- and state-led approaches to the land question in South Africa.

In the second place, I want to show how what has happened can be understood in terms of a combination of more global forces and the specificities of South Africa as a place; a place, moreover, deeply formed by past struggles. In particular, I draw attention to the happenstance coming together of separate forces that have led to the Levubu solution. There is, first, the government's concern about exports, foreign currency earnings as well as its image in the eyes of investors and their watchdogs such as credit ratings agencies; in other words, there is the neoliberal context to consider, about which much has already been written (Bond, 2000; Cheru, 2001; Carmody, 2002; Peet, 2002; Miraftab, 2004; Smith, 2004). The government is concerned about its image, which is to be expected given the implications of exchange rate fluctuations for inflation and its ambitions for economic growth. I argue that all of this leads to a concern about avoiding further land reform failures, which in the case of Levubu has led to the government 
imposing partnerships on the claimants. A second issue refers to conditions more local to South Africa. There is, on the one hand, the skills deficit among historically disadvantaged groups that the government has inherited from the apartheid era (see Bradstock, 2004 p. 3 for a useful discussion) yet with which it must deal in delivering its promises such as restitution. This has contributed to the government's reticence about directly transferring the Levubu farms. Then there is the peculiarly South African social position of African traditional leaders with which the government has had to deal in restitution. In the case of Levubu, and using materials from research with one of the seven claimant communities, I show that the actors leading the claim were installed by the now-deceased traditional leader and that, although the leadership’s authority has been challenged by some beneficiaries, the government has continued to deal with those leaders; that the leaders have supported the partnership plans is not insignificant. Finally, there is the position of agribusinesses to consider. Focusing on the Levubu-based partner, I show that the relative spatial immobility of their investments in the infrastructure of Levubu has compelled them to seek a role after restitution; I also explore some of the dynamics of their role and how they stand to gain from the proposed solution, possibly at the expense of the claimant communities.

In bringing together these materials, I argue that the Levubu case is emblematic of a learning process: ideas imported from outside, from a dominantly market-friendly discourse, have undergone considerable transformation in their application as the policies they informed were forced to confront the realities of the South African situation, its specificities as a place, more accurately as a position in space-time. 
The paper is organised as follows. In the first section I provide a brief history of land reform practice in South Africa, emphasising the global forces of a discursive nature to which it has been subject and the way in which these have been progressively reworked as a result of actual experience of applying them. Particular emphasis will be placed on the restitution programme. I then examine the Levubu case as an exemplar of these forces and practices. I explain the strategic partnership model in Levubu; use materials from research with one of the claimant communities to draw attention to their position in the process; and explain the forces behind the involvement of white agribusiness.

\section{Land Reform in South Africa and the Neo-Liberal Context}

The market-led approach both discursively, according to Bernstein (2002), and as illustrated by the bias of World Bank funding for land transfer schemes, has come to prominence in recent years; redistributive or state-led land reform has therefore had to take a 'back seat' (Feranil, 2005 p.257) to the 'new wave' (Bernstein, 2002) of Market-Led Agrarian Reform (MLAR) (Ghimire, 2001). The MLAR approach 'emerged out of the pro-market critique of the state-led approach to agrarian reform' (Borras, 2005 p.95; Moyo \& Yeros, 2005); it can also be seen as a response to new peasant uprisings in Chiapas, to the activities of the Landless Workers Movement (MST) in Brazil, or to pre-empt 'rural sources of social unrest and political disturbance' (Bernstein, 2002 p.451).

Proponents of MLAR such as Deininger and Binswanger (1999) have argued that state-led policies were, among other things: overly bureaucratic and relied on 'top-down' implementation methods that disempowered beneficiaries; encouraged rent seeking within bureaucracies; 
distorted land markets through prohibitions of land sales; relied upon government-led after-care or support services; and were supply-driven insofar as the state identified land and then sought out beneficiaries. Thus, they have concluded that land reform will be politicised and unsuccessful in achieving its goals when the state assumes a leading role. ${ }^{5}$

In contrast to this, MLAR approaches, 'accord priority to economic efficiency in the marketdetermined allocation of resources' (El-Ghomeny, 2001 p.107) and hence use very different means to effect change in rural areas. Rather than using expropriation of land, for example, MLAR advocates voluntary land reform under 'willing-seller, willing-buyer' principles whereby landowners are paid full market-related values for land sold. MLAR encourages states to adopt 'demand-led' or 'demand-driven' approaches to locate the most determined and 'fittest' beneficiaries: that is, to ‘the most economically efficient producer’ (Borras, 2005 p.95). Finally, MLAR entails a requirement for beneficiaries to develop viable farm business plans before land purchase; and cash grants for beneficiaries to acquire private consultancy for farm developments. In these key respects, then, MLAR aims to achieve change in rural areas by mobilising the forces of the market. Yet it remains to be seen whether MLAR will be successful in its attempt to preempt rural uprisings, or defeat what Moyo and Yeros (2005 p. 24) call the 'progressive forces' that advocate peasant-led land invasions, such as in Brazil (Petras, 1997; Wolford, 2003), or the ‘unique offensive against (capitalist) landed property’ (Bernstein, 2005 p.89; emphasis in original) such as in Zimbabwe. Moreover, and although MLAR has been 'rolled out' in countries

5 As Bobrow-Strain (2004) has noted, however, this separation of the political from the economic is fallacious. In so-called market-led approaches, neither supply nor demand is innocent of power relations. 
in Latin America, Africa and Asia, the question arises as to whether states that adopt MLAR approaches will stick with them.

In this respect, it is important to recognise that places - countries, regions or locales - have their own peculiarities: different histories, spatial arrangements, positions relative to wider flows of capital, ideas, or people. Certainly, places are not immune to goings on elsewhere; rarely are they entirely isolated, unaffected by changes, shifts, or pressures reaching in from afar (for a farreaching discussion of this understanding of Geography see Massey, 2005). It is precisely within the context of such an interrupted, interwoven geography that national land reform (or any other) policy must be implemented, but necessarily with respect to local conditions that are often deeply sedimented historically. We should not be surprised, then, if policies and practices, enjoying some wider resonance and implementation, are mutated, shaped, even abandoned given the wide range of both obstacles and opportunities that can arise in particular countries, or regions.

This is indeed the picture that seems to be taking shape in South Africa, which initially embraced the new market-led approach to land reform - at the advice of the World Bank (Van Zyl et al, 2000; Bond, 2000; Lahiff, 2001; Hall, 2003) - along with numerous other policies of a neoliberal slant (Bond, 2000; Cheru, 2001; Carmody, 2002; Peet, 2002; Miraftab, 2004; Smith, 2004). Embracing the market-led approach led to adoption of a willing-seller, willing-buyer approach to land acquisition, which protects the private property rights of landowners and commits the state to using the market to acquire land for delivery on its promises (Zimmerman, 2000; Lahiff, 2001; Kepe \& Cousins, 2002). According to Deininger (1999), adoption of the 
principle, "was based on the need to maintain public confidence in the land market, and more generally to affirm the government's respect for individual property rights” (Deininger, 1999, p.665). The need for such 'respect' for private property was a major concern of the white minority during the transition from apartheid to democracy, a concern which is ongoing. This sensitivity continues and has been intensified as a result of the way in which neighbouring Zimbabwe rejected the neo-liberal approach in favour of a "fast track" (Bernstein, 2004) expropriation of white-owned land.

Consider now the restitution programme, which provides for the restitution of land rights to persons or communities dispossessed of them after 19 June 1913, and in terms of a racially discriminatory law or practice (Lahiff, 2001; Ramutsindela, 2002; Hall, 2004). Its legal basis is The Restitution of Land Rights Act 22/1994. ${ }^{6}$ The Act provides five forms of restitution: restoration of original land; provision of alternative land; financial compensation; provision of alternative relief; and/or priority access to other government programmes. By March 2004, there were 79693 claims for restitution (Umhlaba Wethu, 2005). According to Hall (2003 p.25), 'between 20\% and 25\%' are rural claims. These are 'large group claims involving hundreds, if not thousands, of people’ (ibid.); they are clustered in Limpopo, Mpumalanga, and KwaZuluNatal (Hall, 2004 p.15). Yet, 'while fewer in number, the rural claims account for the bulk of the restitution programme, since these represent the majority of the people claiming restitution and

$6 \quad$ The Act established a Land Claims Court to adjudicate contested claims in 1996. The Court has the same status as a High Court; hence appeals against its judgment are made to the Supreme Court of Appeal or, in exceptional circumstances, to the Constitutional Court. All claims for restitution had to be lodged with the Commission for Restitution of Land Rights by the end of 1998. The Commission is responsible for investigating claims and preparing them for settlement or adjudication. Regional Commissions were formed in 1999. 
will probably also account for most of the cost' (Hall, 2004 p.16). By mid 2004, around 9,000 rural claims remained unsettled and only six per cent of those settled involved transferring land (ibid.). Not surprisingly, the government has been criticised for its slow pace in completing the restitution programme. In explaining this, attention has focused on the budget for land reform, which in 2001, for example, was only 0.38 per cent of the National Budget, equivalent to the Department of Arts, Culture, Science and Technology (Walker, 2003 p.17). The problems of such a small budget were heightened by the fact that current owners have to be compensated; that restitution has been carried out, in other words, under the constraints of the willing-seller principle. It is notable, then, that the allocation for restitution from the 2005 National Budget, which was 1.18 per cent of the National Budget, has increased significantly from what has been allocated in the past.

Although restitution requires considerable state involvement - the adjudication process, claim processing, buying the land, etc. - and can therefore be understood as a more hybrid type of land reform policy than the government's other programmes, especially redistribution, it nevertheless has been underpinned by the market-led approach. This is because systems for land acquisition initially relied on the state acquiring land from willing-sellers. However, the slant of restitution towards the market has changed as the state has learned about the various shortcomings of its policy.

First, the state has acquired expropriation powers via the Restitution of Land Rights Amendment Act 48 of 2003. Not surprisingly, perhaps, given the high profile given to expropriations in Zimbabwe, the amendment generated debate about the 'potential for abuse of this power by the 
Minister and possible impact of expropriations on investor confidence' (Hall, 2004 p.20). Indeed, when the Minister of Agriculture and Land Affairs exercised these new powers in 2004, it attracted a fair amount of attention from the international media (e.g. BBC News, 2005). Yet, in some restitution cases, such as Limpopo, where 'nearly wall-to-wall claims [cover] much of the province's prime agricultural land like Levubu, Waterberg, and Tzaneen’ (Hall, 2004 p.21), the new powers may have to be exercised to complete the restitution programme against the wishes of landowners who refuse to sell. In short, the state has learned that its commitment to the willing-seller, willing-buyer principle is a major stumbling block.

Second, the state has begun to impose conditions on how claimants can use their land. One aspect here is the government's determination that claimants do not sell transferred land. It has therefore imposed restrictions on using the land as collateral for loan capital. While this means they will have difficulty finding money to invest in new machinery or irrigation works, or indeed to have sufficient working capital, it also protects beneficiaries from the possibility of losing the land in the future. An important dimension of this stance is the desire on the behalf of the government to nurture black farmers: that is, land restitution is one way to alter the racial distribution of land in South Africa; given that the most likely buyers of restituted land would be whites, sale or foreclosure is not something the government is anxious to facilitate.

Finally, the state has altered its approach towards issues of post-settlement assistance. Although only 185 claims had been settled with land transfers as at March 2003 (Hall, 2003), there were already indications by that time that some beneficiaries were failing to maintain agricultural production. Cases began to emerge of what, from the standpoint of earlier uses of the land can 
only be described as regression: failures to maintain yields, abandonment of property, looting of the equipment for want of the capital to put it to work, among other things. An example of this is the Mamathola land claim, near Tzaneen in Limpopo, which resulted in the transfer in 2001 of 1 400ha at a cost to government of R43m. The land was highly developed, and had been operated as a commercial farm enterprise; production began to collapse almost immediately after the hand over. A State Attorney eventually required the government to assume management of the farms in 2003. Although the government blamed the community leadership for the failure, critics of the government's approach to land reform - including some in the white farming community (Du Toit, 2004) - have used the case to draw attention to ineffective government support to restitution beneficiaries. Such deteriorations in productivity suggest that, where restitution restores commercial agricultural land, beneficiaries require extensive skills - ranging from technical and legal to procurement and marketing - that farmers had but which many beneficiaries had been denied the opportunity to acquire. This has bolstered arguments for a degree of post-settlement assistance far beyond what was initially on offer. ${ }^{7}$

In the context of neo-liberalism, it is not entirely surprising that the government has opted for a private solution. Of course, the most private solution is to give the land to the beneficiaries and have them decide how to handle it; however the government is increasingly opting to shift responsibility to the private sector. ${ }^{8}$ A model for such an approach emerged in 2003 in the

\footnotetext{
7 This issue had already widely noted by observers of land reform. Hall (2003), for example, identified three important areas for better post-settlement support: institutional support for the legal entities taking on ownership of the restituted land, support for agricultural production, and assistance to enable beneficiaries to access municipal services on restituted land.

$8 \quad$ Evidence from elsewhere in South Africa confirms the government's willingness to have land reform beneficiaries work in partnership with the private sector (Mayson, 2003).
} 
(former homeland-owned) Zebediela Citrus Estate, Limpopo. Zebediela was taken over by the Agricultural and Rural Development Corporation (ARDC), which was formed in 1996 to oversee the management and restructuring of former homeland assets, farms, and estates. Yet, according to Shaker (2003 p.3) "financial, technical and managerial weakness" in the ARDC meant that it required an R70m annual government subsidy. When this was withdrawn from the National Budget, the ARDC was forced to sell or restructure assets. In the case of Zebediela, the Bjathladi community had a restitution claim, which the Limpopo Land Claims Commission recognised. The need to restore the land and to restructure the asset led the provincial Department of Agriculture and the Land Claims Commission to agree to transfer the asset to the beneficiaries but under the proviso that a 'strategic partner' would manage the land. The arrangement in Zebediela is as follows: There is a management board on which representatives of the workforce, the landowners, and the partner sit (the government is also represented on the board, although without voting rights). The partner signed a lease agreement for fifteen years and pays an annual rent to the landowners. Profits are shared between the landowners, the workers and the partner according to the following formula: partner: fifty per cent; landowner: thirty-five per cent; workforce: fifteen per cent. In return for the higher share, the partner provides working capital for the enterprise, a management team and commits to providing accredited training to the landowners and workers, so enabling some of them to assume management of the estate at the end of the lease agreement. ${ }^{9}$

\footnotetext{
$9 \quad$ It has to be pointed out that, while Shaker (2003) does not identify the strategic partner, the Financial Mail (October 2004) claims it is the Boyes family group. However, a black economic empowerment (BEE) company, South African Farm Management (SAFM) was identified as the partner when I visited the estate in 2004. The relationship between the Boyes group and SAFM is not exactly clear: according to one member of SAFM's board, the Boyes group is only an 'investor' in SAFM; yet many of the white farmers in Levubu, who know the Boyes family, claimed that SAFM was a black
} 
What we see, then, is that South Africa's land restitution policy - which was and remains influenced by market-led approaches - has begun to shift towards a more vigorously interventionist stance. There is the shift towards expropriation to consider, as well as the government's stance of imposing new forms of post-settlement assistance on land reform beneficiaries. It has therefore encouraged and, in some cases, compelled beneficiaries to establish partnerships with private consultants or agribusinesses. It is to a fuller discussion of these issues as they have been played out in the Levubu case that the paper now turns.

\section{The Case of Levubu}

The area known as Levubu is located on the southern piedmont of the Soutpansberg Mountains between Makhado and Thohoyandou. The restitution claims refer to removals in the late 1930s. The Union of South Africa displaced thousands of Africans from the area to make way for an irrigation scheme for the settlement of poor whites. The claimants consist of seven communities. They have used archival and oral evidence about the dispossessions to support their claims. The sub-tropical climate in Levubu is ideal for the commercial farming of mango, avocado, banana and macadamia nuts. Around two hundred whites own the farms. Although many of them dispute the restitution claims and refuse to sell their farms, a group of fifty farmers did agree and this has led to the first group of purchases, which means that the remaining farms - owned by the group who refuse to sell - may have to be expropriated to complete the restitution process in the area.

economic empowerment front for the Boyes group. Adding to the confusion, a government official told me in an interview that SAFM consisted of 'comrades' (Interview with official from Limpopo Land Claims Commission, October 2004). 
My research on the restitution issue in Levubu involved thirty semi-structured interviews with white farmers. Some of them had agreed to sell, while others were refusing. One group of farmers, in particular, was positioned to become a strategic partner with some of the claimants. I conducted five interviews with one member of this group. Wherever possible, I tried to triangulate information gathered from these interviews. I also conducted research with members of two of the communities claiming land in Levubu. This included interviews with community leaders ${ }^{10}$. I focused most intently on interviews with members of the Ravele Land Claims Committee as well as ordinary Ravele beneficiaries. I conducted a total of forty interviews with beneficiaries in their homes to learn what they knew about the process, what they believed would happen with their land, what they would like to happen with their land, and how they believed they could influence the process. ${ }^{11}$ Finally, my research included semi-structured interviews about the Levubu land claims with numerous government officials, including with the Limpopo Land Claims Commissioner.

\subsection{Imposing the Levubu 'solution'}

The research revealed that the restituted land will be transferred under the following restrictions. First and foremost, and because of the value of the land and its commercial use, the beneficiaries cannot re-settle it. This condition is not unique to Levubu; according to one government official,

\footnotetext{
10 This includes community structures such as the Civic Association, the Tribal Council and faithbased groups.

11 Talking about restitution was a sensitive matter. There were countless rumours about who was really going to benefit from the land claims: some said that traditional leaders would keep the benefits for themselves; others accused their respective land claims committees of withholding information with a view to controlling the transferred land for their own personal benefit.
} 
only 'where farms aren't commercially viable, people can re-settle' (Personal Interview with official from Limpopo Land Claims Commission, September 2004; my emphasis). It must be stressed that this is a major imposition on the claimants, many of whom do not have sufficient access to land and who would like to farm the land there.

Second, the government has disallowed the communities to have the land restored and then lease it back to the white farmers, an option many (if not all) of the farmers favoured and which many said was the reason they had agreed to sell. On this issue, one government official said:

As a Province we do not overwhelmingly receive this [sic]. This thing of leasing back cannot be a leasing back and left at that. Some of the farmers are proposing is that, "You buy my land, you give me $\$ 10 \mathrm{~m}$. I take it and put it in my bank and pay all my debts.” And then I come back and say, “Ok, I want to lease this land and just continue making money, right? I'm not going to train your guys so one day you can come and run it.” Actually you have not changed anything. You are creating perpetual dependence. The community just gets rental at the end of the month. (Personal Interview with official from Limpopo Land Claims Commission, October 2004).

Third, then, the claimants must accept a strategic partner to manage their land. One member of a Land Claims Committee stated that, 'Dr. Motsoaledi [then provincial political head of the Department of Agriculture] made it clear that, "if you want the land to be returned, you must agree to take on board a strategic partner.” You see, this is the government's plan.' (Personal Interview, April 2004). 
The specific arrangements in Levubu are similar to the model used in Zebediela (Shaker, 2003), although there will be two strategic partners (SP) working with the beneficiaries in Levubu. The beneficiaries, who enter into a Joint Venture Company (JVC) with one of the agribusinesses, receive an annual lease payment for use of the land. They also share the profits with the SP. Because the beneficiaries cannot raise capital on their own given the constraints on using the land as collateral for loans, the SP provides working capital. One government official sought to give this a more positive slant by emphasizing that having the partner bring working capital would mean that:

He will make sure it does not go down, unlike where he has leveraged the land and where the farm goes down the bank takes the land, which was a policy decision of this government. We cannot afford it, otherwise we'll have a situation where we give land, the bank takes it, and sells it to a white landowner. (Personal Interview with official from Limpopo Land Claims Commission, October 2004)

The Levubu settlement also includes a skills transfer plan, which is intended to enable beneficiaries to take full control of the farm enterprises at the end of the fifteen-year lease period. The intention is to create a new group of black farmers in Levubu, one that will potentially highlight the benefits of the government's land reform programme. ${ }^{12}$ This has a strong

12 Importantly, both partners pitched their operations to the government as consisting of black partners as per the government's concern that land reform comply with its black economic empowerment intentions. As I have already noted with regards to SAFM and as appears to be the case with the other 
empowerment element because, as one official stated, the government task is to be 'a catalyst for change and transformation' (my emphasis), and the skills transfer plan is central to achieving this goal. In short, the emphasis on training claimants to farm underlines the developmental goals of the government and its distancing from a more market-led process. The government does not just want to insert the claimants as landlords; it wants to develop them.

Adoption of the partnership approach evidently reflects the government's experience of highprofile cases of restitution failures in other parts of South Africa. Indeed, officials explained the government's position with respect to the Levubu case through reference to these failures. Collapse of the restituted farms at Mamathola, for example, clearly led the Limpopo Land Claims Commission, along with the Department of Agriculture, to look for alternative ways to provide post-settlement support. One official noted that:

The assumption was communities are ready; communities want to become commercial farmers. Nobody really thought about the post-settlement implications of what we were doing, nobody. And then finally when Mamathola happened, fortunately for us this happened, everybody started to say, “Hey, we need post-settlement support.” We can’t hand back highly commercial farms to communities and expect them to survive on their own. (Personal Interview with official from Limpopo Land Claims Commission, September 2004).

partner, the financial backing and leadership positions of these companies is white, not black; this does not mean, however, that either company is not serious about BEE. 
There is, therefore, some empirical basis for the government's reluctance to opt for direct transfer given that 'the claimant cannot come on and expect to run the farm in a day' (Personal Interview with official from Limpopo Land Claims Commission, October 2004). And rather than allowing claimants to re-settle the land or have them lease the land to other farmers, the government opted for privatised post-settlement because, ‘we believe that it’s not only [about returning the] land, [the partnership plan is] a long process, maybe fifteen years, maybe twenty years, but it has to happen and it has to happen this way [...] we really want it to be a private deal' (Personal Interview with official from Limpopo Land Claims Commission, October 2004; my emphasis).

The partnership arrangement can therefore be viewed as a form of privatised post-settlement support that minimises the need for government-provided support but which also places severe limitations on how the rightful landowners can use their land. It reflects the learning process through which land restitution practice has moved - from a stance of favouring direct transfer to imposing restrictions on communities - as well as the government's desire to minimise what it needs to spend. In this sense, the tensions of national finances in the context of neo-liberalism reach into Levubu.

Yet, despite the way the government has imposed its vision for restitution in Levubu, the balance of political forces has been such as to facilitate its implementation. Not only have they been able to obtain the support of the communities involved, partly through the ability of African elites to control the whole negotiations process (possibly with a view to side payments to themselves for 
their trouble); but in addition the calculations of white agribusiness have also lent impetus to the feasibility of the plan.

\subsection{The claimants}

Turning to the communities, a key issue is the role of traditional leaders. As has been noted elsewhere (e.g. Rangan and Gilmartin, 2002; Claassens, 2001), the post-apartheid government has not sufficiently challenged traditional authorities in the former homelands and Bantustans. According to Rangan and Gilmartin (2002 p.639), traditional leaders: 'retain powers to control spaces in de facto homelands'; mostly 'function on the principle of hereditary rule'; and exercise 'traditional customary law in former Bantustan areas.' Thus, while the Constitution of South Africa has abolished homelands, enshrines a Bill of Rights, and accords equal rights to women and men, the situation in the former homelands and Bantustans highlights contradictions in the constitution. The continued strength of traditional leaders has meant that, in land reform in general, and restitution in particular, the government has had to reconcile its determination to transfer land with the presence of traditional authorities that have the potential to undermine the egalitarian character of land reform.

In investigating restitution of land rights in Levubu, one area of focus for my research was the internal dynamics of the claimant communities, especially in regards to the role of traditional leaders. I use here materials from research on the Ravele beneficiaries, whose ancestors were displaced from their land in Levubu in the late 1930s. They were 'granted' land by the Union of South Africa in present-day Mauluma, 20km from Levubu. Today, the village has around 5000 inhabitants. Many are not members of the restitution claimant community; furthermore, only 
twenty-two percent of the registered beneficiaries reside in Mauluma. ${ }^{13}$ The late Ravele traditional leader was a politician in the former Venda Bantustan. Before he died, he created a Land Claims Committee and appointed its leaders. They remain in their position of power to this day; even the new traditional leader has not been able to replace them. Not surprisingly, given all of the meetings the leaders have attended with government officials, non-governmental organisations, and the strategic partners, the leadership of the Ravele beneficiaries has acquired considerable knowledge of the claim, the legal and procedural process, and on how the land will be used under the terms of the partnership.

Yet numerous beneficiaries claimed the leadership had not been forthcoming with information about the claim. Mauluma has structures that the Land Claims Committee arguably should have kept informed on what was happening with the claim. Khoro (Tribal or Village Council), for example, meets in Mauluma every two weeks. Although not everyone living in Mauluma is a Ravele beneficiary and neither do all the beneficiaries live there, Khoro presented a regular opportunity for the committee to keep people informed. According to numerous beneficiaries, however, it refused to do so. Indeed, when I asked about this, one leading member of the committee stated that 'you see, in terms of the [Restitution of Land Rights] Act, the Land Claims Committee must report to the beneficiaries; Khoro is not a structure we must report to' (Personal Interview, March 2005; respondent’s emphasis).

13 The land claims committee claimed this number was an under-estimate. They said many of the inhabitants of Mauluma should have but did not sign up as beneficiaries because they believed by registering they would have to move back to the land. Space does not allow me to discuss here why so many of the beneficiaries in Mauluma did not want to leave, or what this might mean for restitution policy. 
Others among the beneficiaries believed the Land Claims Committee had deliberately guarded their positions. One beneficiary even went so far as to claim that,

People are not as aware of what is going on as they should be and I think this is more by design. It is not accidental that people are not aware. [...] It's by design. As you are aware, the people on the Land Claims Committee [...] derive their convictions on the point that says, 'we have been involved in this process since as early as 1996'. They regard themselves as custodians of the process. They don't believe that anybody else deserves to know more than they know. They believe they have got the right to decide what other people should know and shouldn't know and, for them, anybody else who gets to know anything about the process, for them, it’s a privilege. (Personal Interview, May 2005).

It was not clear why the leadership was so intent on maintaining this sort of secrecy. It is not inconceivable that they had the best interests of the beneficiaries in mind; nor, however, is it too extreme to suggest that they intended to make personal gains. Indeed, the latter possibility was most commonly raised by beneficiaries. They certainly are well positioned to gain as a result of holding positions on the Board of Directors of the Joint Venture Company, especially if those positions are remunerated; even if they are not, whomever fills those positions will have privileged knowledge of the situation. Another possibility is that the leadership wants to control the legal entity that will oversee how income from the land will be spent. Indeed, income from the land, via the annual lease payment and shares from the farm-based profits, may turn out to be quite considerable, possibly in the millions of Rand annually. 
Although the research cannot determine exactly what the leaders intend to do with the knowledge and power they have accumulated, it is clear that they were major supporters of the strategic partnership approach. This seems to have a lot to do with why the government's imposition of the partnerships did not experience anywhere near the level of resistance one might expect given that the government is telling the beneficiaries how they can use their land. Further, though the leadership was supportive of the partnership proposals, interviews with ordinary beneficiaries revealed not only a lack of knowledge about the land claim - among numerous other things, they did not know the number of farms that would be transferred, the potential strategic partners with whom the government was determined they would have to work, or whether beneficiaries would be allowed to have their own portion of land - but also an acknowledgement that they had had negligible influence on how the claim had progressed. Again, understanding why beneficiaries were so unaware of what was going on and why they had seemingly been excluded from the process was not easy. Among other things, leaders of the Land Claims Committee said that 'the people do not understand this process; all they want is for us to tell them when we will get the land back' (Personal Interview, March 2005). Yet it is not unreasonable to suggest that the beneficiaries had been deliberately kept in the dark by the leadership.

Thus, despite government claims that restituted land will be returned to democratically elected and organised legal entities such as Communal Property Associations or Trusts, evidence from my research with the Ravele beneficiaries suggests otherwise and draws attention to the government's seeming indifference to the issue of community democracy. Indeed, the 
government was continuing to negotiate and meet with members of a Land Claims Committee that was not democratically elected and was suspected by the beneficiaries of pursuing personal gain. I argue that this helps to explain the acquiescence of the Ravele beneficiaries to the government's plans for the restituted land. The Levubu solution has turned out to be partly a deal between a small and un-representative group of community leaders and the government. The other party involved were the two agribusinesses that emerged as partners during 2004. It is to the partners that I now turn.

\subsection{The strategic partners}

The beneficiary communities are only part of the equation which has made this odd hybrid arrangement politically feasible. There is also the interest of the white agribusiness. One of the two agribusinesses involved, Mavu Management Systems, consists of white farmers from Levubu and the surrounding area. ${ }^{14}$ They own upstream agricultural suppliers, downstream processing facilities (nut drying and hulling, juice processing), and have marketing channels to domestic and foreign buyers. The MMS farmers stated that they believed restitution via direct transfer of land to the beneficiaries would place their fixed up- and downstream investments, which have been developed since the 1980s, at risk. This is because they shared with the government the view that the beneficiaries would not be able to farm the land adequately. This would place the supply of high quality raw materials to their processing facilities and marketing operations in jeopardy. One possible strategy, which the MMS farmers, in common with most of the farmers in Levubu, had favoured, had been to lease back the land from the claimants; as noted, however, the government was opposed to this. Entering into partnership arrangements

14 My research was most closely involved with MMS; representatives from the other partner, SAFM, were not as willing to discuss their role in Levubu. 
with the claimant communities was therefore the only way for the MMS farmers to ensure their raw material supply. As one of the farmers in MMS noted, 'the best way to [secure your raw material base] is to farm it yourself'. He continued thus:

Look, to be honest, if I didn't have my investment in the factories I wouldn't have been a strategic partner. [...] I would have been out of here. [...] Remember, a factory, if your raw material basis is not secure, it's actually just a heap of stainless steel.

There were other concerns. The other potential strategic partner, SAFM, was positioning itself to manage the Levubu farms. MMS therefore had another incentive to get involved: 'My factory processes the stuff. If [another partner] takes over the whole 10 000ha [in Levubu] and takes over my raw material base, then I'm actually in dire straits, right?' If ensuring future supplies of raw materials was the primary incentive for MMS, another concern was the overall commercial viability of Levubu. The farmers in MMS own upstream facilities - nurseries and a supply company - the future profitability of which depends on a vibrant agricultural economy in Levubu. And there is also the issue of the time and energy expended in establishing markets, both in South Africa and overseas, which would show limited return if restitution in Levubu was to be a failure.

So there were necessities impelling them in the direction of performing the role that the government has been looking to them to perform. There were also conditions of a more facilitative sort regarding the transition process between individual private ownership and the partnership arrangement. Hugely important here is that under South African labour law, they are 
going to be able to draw on the knowledge of existing workers on the land to be restituted. This knowledge is important because, as another farmer noted, the transition from one owner to the next can be problematic:

This farm we took over: It took me days to actually discover the irrigation system. When we bought the farm, the grass was this high, I cut the grass and I said, “ok, he has irrigation” - small sprinklers next to the trees - and I said, “ok, if he’s got irrigation, he must have a main line and a valve.” And I took all six of my people and asked them to look around for a valve and it took me a week's chopping down of trees and there wasn't one because it wasn't connected... You don't take over a farm and run it. If you take over this farm, you're not going to run it like I've been running it. It's going to take you at least 12 months to get yourself stationed. (Personal Interview, October 2004).

But the farm workers are critical in another sense. Not only are they a source of knowledge, if MMS can alter the organisational structure and the division of labour on the farms, then that can enable a radical reduction in the costs of the overall operation. One farmer in MMS commented on this aspect:

...you must look at how people have farmed up till now in South Africa... you had a white farm owner and a black, traditionally what you call a "boss boy". And he was actually doing most of the work. It's going to be a three-year phasing in where you have to change these guys, these black farm managers. Because even though they have done the work, they didn't assume responsibility. You have to get them to a point where they 
assume responsibility. Like my farm managers: they're all black. Ok. They run their farms as if it's their own property. They assume full management responsibilities. They know exactly what the cost impacts of each decision is (sic.) and they know how it impacts on their incentive bonus at the end of the year. Now that system is not in place in Levubu, under the traditional system. But the people are there. And I don’t think those people are different from my people ... you have to go in and change their mindsets. The technical expertise is there. They're on the farms. So it's a question of managing those guys and integrating the different management philosophies.

It is significant - from the perspective of understanding the coming together of various contingencies of South Africa as a place - that the MMS farmers are in position to draw on this expertise owing to the protections of recent South African farm labour legislation. For example, The Agricultural Labour Act 147/1993 and Labour Relations Act 66/1995 both provide protection for farm workers, which MMS is likely to exploit and which will help the partners achieve a smooth transition. This is especially the case given that the beneficiaries may expect jobs to become available on what, after all, will be their land. The labour laws, however, will enable the partners to resist any calls for widespread redeployment of workers. For sure, members of the beneficiary communities will eventually replace these workers and farm managers. But as, with not a little relief, one of the MMS farmers explained it:

...you've got labour laws in South Africa, which make it practically impossible to dismiss them [the current workforce], which I'm so glad about! So, yes, through normal attrition, definitely, in ten years, you train a new class of managers. It makes absolute 
sense [but] If you want to dismiss a farm manager of 20 years experience, and you have to pay him one week for every year of service, and you want to dismiss a few thousand people, then you're looking at a serious pain.

Thus, the calculation of MMS to become a partner encompasses a wide range of aspects, from the need to secure a supply of raw materials so that returns on earlier, long-lasting investments can be achieved, to ensuring that problems in the transitional period are minimised. And add to the attractions of the scheme, the agribusinesses will be, courtesy of land restitution, making gains from far more land than they ever controlled before restitution. So despite the risks and challenges ahead for a partner such as MMS, if the post-restitution environment is negotiated effectively, a large windfall may be in the offing:

Where in the whole wide world will somebody come and buy your assets from you and then give it back to you at no cost plus $50 \%$ of the share back to you? Where will that happen? And that's what's happening in Levubu. And they're not only buying my assets, they’re giving me three times more, four, five times more assets. They're going to spend R231m and basically give 50\% of R150m to MMS. Where in the world will you get that asset base for basically nothing? What's your investment? Your working capital? Where’s your exposure?

\section{Discussion and conclusions}

The Levubu ‘solution’ draws attention to a hybrid approach to restitution. Consider how the government acquired land for restitution in Levubu: reflecting the influence of market-led 
approaches, it has not used expropriation in the process of land acquisition; rather, it has relied on the willing-seller, willing-buyer principle. In Levubu, this has led fifty-one farmers to agree to sell. ${ }^{15}$ Yet, while the approach to land acquisition reflects the market-led approach, the way in which the government has sought to transfer land is certainly not. The state has imposed farreaching restrictions on how the beneficiaries can use the land; restrictions that, as a model for restitution on commercial agricultural land of this type, have not been tested elsewhere in South Africa. By so doing, it has acted as the 'guardian' (Bernstein, 2002) of the beneficiaries' interests. This aspect highlights more developmentalist or state-led approaches to land reform. In my view, therefore, restitution in Levubu is a fusion of these two ways to address land questions.

I argue that this fusion can only be understood in terms of the geo-historical context of South Africa as a place. For example, plans such as those in Levubu are closely bound up with the South African state's wariness about its foreign currency earnings, the rate of exchange and inflation targeting, which is 'the anchor of monetary policy in South Africa' (Business Day, November 8 2005). Furthermore, precisely how South Africa's approach to land reform is viewed by international observers, including not just potential inward investors but also the allimportant credit rating agencies, has inserted an element of discipline on the state, which helps to

15 Admittedly, the government has not had the degree of success it would have perhaps anticipated. In Levubu, as in other parts of South Africa, many landowners still refuse to sell. What has happened elsewhere, therefore, is that the state has begun to expropriate land. When I interviewed a government official in Limpopo with responsibility for land reform and asked about the farmers who refuse to sell for restitution purposes, the official noted that, 'we will declare disputes with [those who refuse to sell] and we will expropriate. [There is] No other route. We will expropriate.' (Personal Interview with official from Limpopo Land Claims Commission, September 2004). 
explain why it has been reluctant to use its expropriation powers; events north of the Limpopo River in Zimbabwe in particular have shown to outsiders the perils of expropriation and it seems fair to say that South Africa has been wary of taking such an approach. I also argue that the interest of international observers extends to how the government deals with restitution in areas such as Levubu. High-profile failures, with tours to the struggling farms for visiting foreign journalists, organised by the local white farmers, would not look good for the government's image. In these ways, then, the national state is caught up in a neo-liberal bind from which it cannot easily escape and which influences the way policy is implemented on the ground. Clearly, then, the Levubu 'solution' has also emerged from the experience of implementing land reform policy and, in particular, the 'reality' that beneficiaries cannot achieve success without extensive support. This is as much a part of the apartheid inheritance as the land question itself.

Finally, there is the disposition of political forces around the Levubu case. This includes the acquiescence of the claimants and the interest of white agribusiness. As I have discussed, the former aspect is closely related to the authority of traditional leaders and how leaders among the claimants have guarded their positions, restricted the flow of information, possibly with a view to personal gain. The latter was driven by considerations of both potential losses and also potential gains. There is the issue of securing access to a certain quality and quantity of raw material and the prospect of the government buying assets and then effectively returning them to MMS. Furthermore, the contingent role played by South Africa labour legislation - which holds out the prospect of a smooth transition and the possibility of restructuring labour costs on the farm businesses to their advantage - is not inconsequential to the calculations of MMS. 
An unanswered and important question about use of strategic partnerships is that, while they are touted by government officials as a pathway to success, how things will work out is actually a good deal more uncertain. A particular concern is that over re-investment. Given the fifteen-year time horizon for the partnership, how seriously will the strategic partner push reinvestment of earnings in the project, particularly if there is pressure from the community to spend the profits instead on upgrading community infrastructure, bursaries, and the other things that have been mentioned.. One large-scale, export-oriented farmer commented on this aspect:

Let’s say I become a strategic partner and the term is fifteen years, how do you think this farm is going to look right in fifteen years? [...] I mean, there's a big difference between return on investment and profit. I can go to a very high profit point very quickly... if I’m an interim partner I will go for the profit margin...I mean, it takes seven years for a citrus tree to come into full production. Do you think I'm going to plant new trees? No, I'm going to go for the profit margin, it's as simple as that... Ownership means return on investment, not profit. I mean, I came here and up until today, this company has never paid a dividend, we’ve ploughed back every cent. We draw salaries, we all draw salaries, but we have never paid a dividend...That's the principle of what I'm talking about. So if the owner hasn't got the drive, don't think that your manager is going to have it. I mean, you appoint a manager, they always say, 'What is the bonus system?' And the bonus system is always profit-related, so what do they drive? The profit. (Personal Interview, November 2004). 
I asked a government official involved in the Levubu restitution claim about the issue of sincerity, re-investment, and whether the government will intervene to ensure partners do not take advantage of the beneficiaries.

Official: You [the partner] have to give us a deal to say what is your expansion plan. What is your investment plan? At the same time, you have got the claimant communities, the workers and the SP and government as an overseer, a representative of government who'd on a daily basis be part of the process...

AF: But that's going to depend on how sharp is that person.

O: Yeah, obviously, the idea is that person is not necessarily an individual. He's there representing an institution. If needs be, if we need to get somebody else in, if you think that this guy is not giving proper fertilisation to the roots then we can get the relevant government structure to investigate because this man is reaping these plants and the next five years he is going to leave and you have to re-plant everything.

AF: But what is the penalty? How does the government exert discipline?

O: Well, those are the things that are being worked on. [...]But in the end, it's a very big challenge if a guy tries to play fun and games and in a SP arrangement we have to accommodate for that. It becomes a private issue but we hope in the line that we have structured it will be a success. I think we are going to have to learn to work with the SPs. 
We are learning, we are looking at how they are doing. I think if production is going well, everyone will be excited and happy. But the real truth will come if things start to go down. Then you will see the true colours of everyone! But the taste of the pudding is in the eating and we are currently trying to eat it and see how does it taste.

Despite this official's confidence that the government will be able to monitor the Levubu case effectively, it obviously remains to be seen how successful it will be. On the other hand, one of the strategic partners has a stake in the area in the form of facilities whose future commercial viability depends on making the project a success over a longer term period than the fifteen years. Government, too, has a stake in securing employment on the farms and maintaining exports; and, of course, the beneficiaries have a major stake, albeit one that they may be tempted to trade off against consumption. Moreover, the large amounts of money involved could lead to disputes. Some of the better positioned could stand to secure significant personal gains. There are also challenges ahead relative to monitoring the activities of partners, ensuring they truthfully state financial earnings, not manipulating accounts, buying over-priced inputs, or selling output at under-market rates. For communities that obviously suffered from dispossession and then under apartheid, restitution promises to bring much-needed money. Yet precisely who will control the money that will come from the land is not clear. Some, but by no means all, community members monitored the land claim closely and appeared to be jockeying for position to influence how income from the land would be spent. Others seemed resigned to the fact they would have little or no influence. 
What the strategic partnership approach certainly generates is a new and important social structure among the Ravele beneficiaries, the Communal Property Association, which will have the potential to create enduring changes in Mauluma. For example, the Ravele Land Claims Committee stressed that income from the land would be used to 'develop' Mauluma: that is, to improve schools in the village, lay a new road surface, and possibly to build new sports facilities. Future research will be needed to assess what, if anything, the beneficiaries have gained from this approach to restitution; and to examine how the CPA, a new and potentially wealthy structure, will interact with existing structures, including the institution of traditional leadership.

\section{References:}

Aguilar, F., 2005. Rural land struggles in Asia: overview of selected contexts. In: Moyo, S. and Yeros, P. (Eds.) Reclaiming the land: the resurgence of rural movements in Africa, Asia and Latin America. Zed Books, London, pp. 209-234.

BBC News, 2005. South African white farms to be seized. September 23, 2005.

$<$ http://news.bbc.co.uk/2/hi/africa/4273890.stm> Accessed January $5^{\text {th }} 2006$.

Bernstein, H., 2002. Land reform: taking a long(er) view. Journal of Agrarian Change 2 (4), 433463.

Bernstein, H., 2004. 'Changing before our eyes': agrarian questions and the politics of land in capitalism today. Journal of Agrarian Change 4 (1), 190-225. 
Bernstein, H., 2005. Rural land and land conflicts in Sub-Saharan Africa. In: Moyo, S. and Yeros, P. (Eds.) Reclaiming the land: the resurgence of rural movements in Africa, Asia and Latin America. Zed Books, London, pp. 67-101.

Bobrow-Strain, A., 2004. (Dis)Accords: the politics of market-assisted land reforms in Chiapas, Mexico. World Development 32 (6), 887-903.

Bond, P. 2000. Elite transition: from apartheid to neoliberalims in South Africa. Pluto Press, London.

Borras, S. Jr., 2003. Questioning the Pro-Market Critique of State-Led Agrarian Reform. European Journal of Development Research 15(2), 105-128.

Borras, S. Jr., 2005. Can redistributive reform be achieved via market-based voluntary land transfer schemes? Evidence and lessons from the Philippines. The Journal of Development Studies 41(1), 90-134.

Bradstock, A., 2004. Implementing land reform in South Africa's Northern Cape Province. Agricultural Research \& Extension Network 137, 1-13.

Business Day, 2005. No sudden moves: science and psychology in monetary policy. November 8, 2005. 
Carmody, P., 2002. Between glohbalisation and (post) apartheid: the political economy of restructuring in South Africa. Journal of Southern African Studies 28 (2), 254-275.

Cheru, F., 2001. Overcoming apartheid's legacy: the ascendancy of neoliberalism in South Africa’s anti-poverty strategy. Third World Quarterly 22 (4), 505-527.

Claassens, A., 2001. 'It is not easy to challenge a chief': lessons from Rakgwadi. Programme for Land and Agrarian Studies, Research report 9. Cape Town, SA.

Deininger, K., 1999. Making negotiated land reform work: initial experience from Colombia, Brazil and South Africa. World Development 27 (4), 22.

Deininger, K., Binswanger, H., 1999. The evolution of the World Bank’s land policy: principles, experience, and future challenges. The World Bank Research Observer 14 (2), 247-276.

Du Toit, P., 2004. The great South Africa: land scandal. Legacy Publications, South Africa.

El-Ghonemy, M., 2001. The political economy of market-based land reform. In: Ghimire, K. (Ed.), Land reform and peasants livelihoods: the social dynamics of rural poverty and agrarian reforms in developing countries. Intermediate Technology Development Group Publishing, London, pp.105-130. 
Feranil, S., 2005. Stretching the 'limits' of redistributive reform: lessons and evidence from the Philippines under neoliberalism. In : Moyo, S. and Yeros, P. (Eds.) Reclaiming the land: the resurgence of rural movements in Africa, Asia and Latin America. Zed Books, London, pp. 257282.

Financial Mail, 2004. Strategic partner model for commercial farming shows promising results. October, 222004.

Ghimire, K., 2001. Land Reform at the end of the twentieth century: an overview of issues, actors and processes. In: Ghimire, K. (Ed.), Land reform and peasants livelihoods: the social dynamics of rural poverty and agrarian reforms in developing countries. Intermediate Technology Development Group Publishing, London, pp.1-22.

Hall, R., 2003, Rural restitution: Evaluating land and agrarian reform in South Africa. Programme for Land and Agrarian Studies, Cape Town, SA.

Hall, R., 2004, Land and agrarian reform in South Africa: a status report 2004. Programme for Land and Agrarian Studies, Cape Town, SA.

Harvey, D., 2005, A Brief History of Neoliberalism. Oxford University Press, New York.

Jacobs, P., 2003. Support for agricultural development. Programme for Land and Agrarian Studies, Cape Town, SA. 
Jessop, B., 2002. The future of the capitalist state. Blackwell Publisher, Cambridge, UK.

Kay, C., 2001. Reflections on rural violence in Latin America. Third World Quarterly 22 (5), 741-775.

Kepe, T., Cousins, B., 2002. Radical land reform is key to sustainable rural development in South Africa. Programme for Land and Agrarian Studies, Cape Town, SA.

Lahiff, E., 2001. Land reform in South Africa: is it meeting the challenge? Programme for Land and Agrarian Studies, Cape Town, SA.

Lahiff, E., Cousins, B., 2001. The land crisis in Zimbabwe viewed from south of the Limpopo. Journal of Agrarian Change 1 (4), 652-666.

Levin, R. and Weiner, D. (eds), 1997. Struggles for Land in Mpumalanga, South Africa. Africa World Press, NJ/Eritrea.

Massey, D., 2005. For space. Sage publishers, London.

Mayson, D., 2003. Joint ventures. Programme for Land and Agrarian Studies, Cape Town, SA. 
Miraftab, F., 2004. Neoliberalism and casualization of public sector services: the case of waste collection services in Cape Town, South Africa. International Journal of Urban and Regional Research 28 (4), 874-892.

Moyo, S., Yeros, P., 2005. The resurgence of rural movements under neoliberalism. In: Moyo, S. and Yeros, P. (Eds.) Reclaiming the land: the resurgence of rural movements in Africa, Asia and Latin America. Zed Books, London, pp. 8-64.

Peet, R., 2002. Ideology, discourse, and the geography of hegemony: from socialist to neoliberal development in postapartheid South Africa. Antipode 34(1), 54-84.

Peters, P., 2004. Inequality and social conflict over land in Africa. Journal of Agrarian Change 4 (3), 269-314.

Petras, J., 1997. Latin America: the resurgence of the left. New Left Review 223, 17-47.

Rangan, H., Gilmartin, M., 2002. Gender, traditional authority and the politics of rural reform in South Africa. Development and Change 33 (4), 633-658.

Rumutsindela, M., 2002. The perfect way to ending a painful past? Makuleke land deal in South Africa. Geoforum 33, 15-24. 
Sauer, S., 2001. The experience in market-assisted land reform in Brazil. In: Morales, H., Putzel, J., Lara, F., Quitoriano, E. Miclat-Teves, A., (Eds.) Power in the village: agrarian reform, rural politics, institutional change and globalization. University of the Philippines Press, Philippines.

Shaker, M., 2003. Restructuring of state asset in Limpopo. Service Delivery Review 2 (2), 73-77.

Smith, L., 2004. The murky waters of the second wave of neoliberalism: corporatization as a service delivery model in Cape Town. Geoforum 35, 375-393.

Umhlaba Wethu, 2005. A quarterly bulletin tracking land reform in South Africa. Programme for Land and Agrarian Studies, Cape Town, SA.

Van Zyl, J., Vink, N., Kirsten, J.F., 2000. South African Agriculture in transition. University of Pretoria, South Africa.

Walker, C., 2003. Piety in the sky? Gender policy and land reform in South Africa. Journal of Agrarian Change 3 (1 and 2), 113-148.

Wolford, W. 2003. Producing community: the MST and land reform settlements in Brazil. Journal of Agrarian Change 3 (4), 500-520.

Zimmerman, F., 2000. Barriers to participation of the poor in South Africa's land redistribution. World Development 28 (8), 1439-1460. 
Figure 1: The Levubu area of Limpopo Province

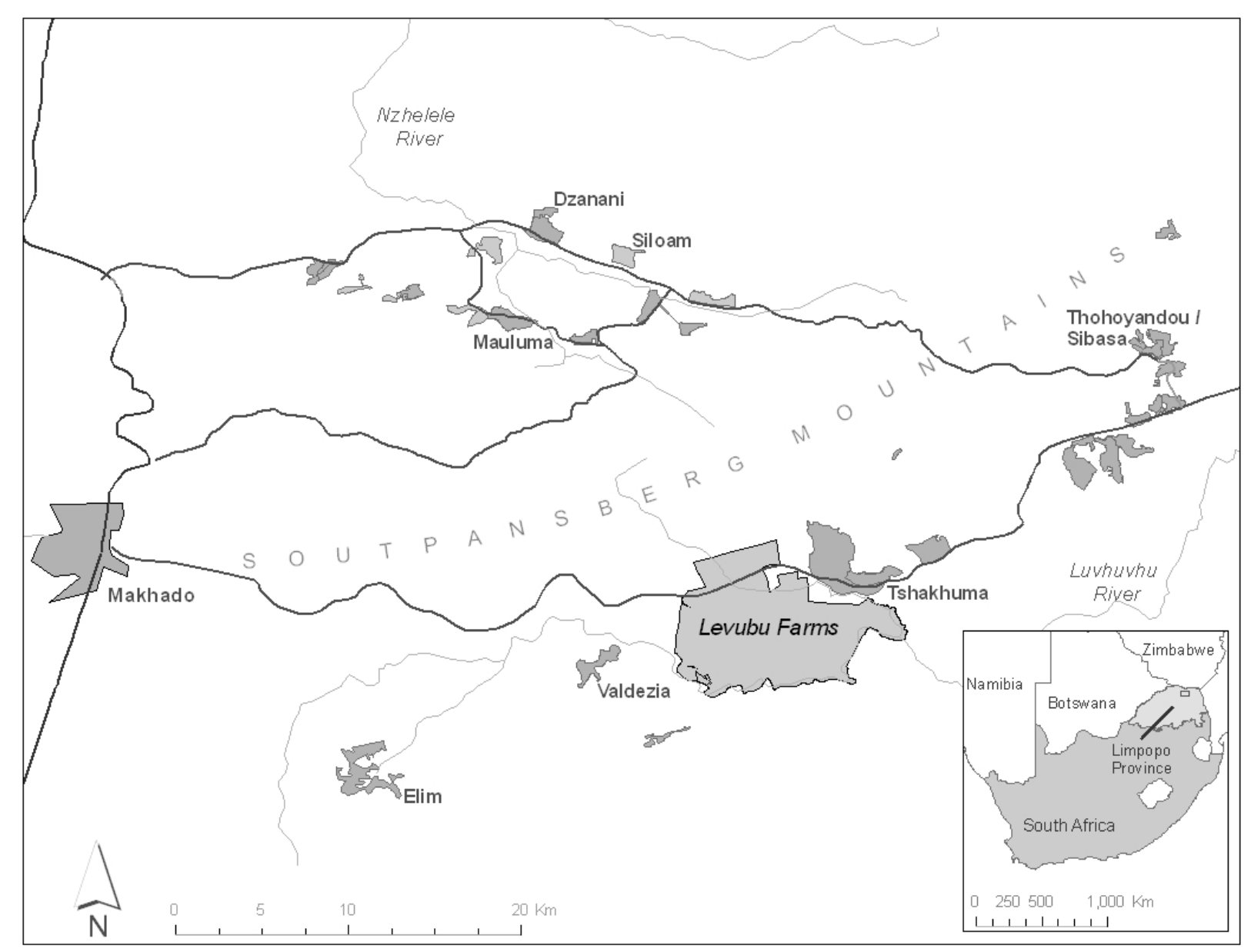

